\title{
Shade-induced Grass-Tetany-Prone Chemical Changes in Agropyron desertorum and Elymus cinereus
}

\section{H. F. MAYLAND AND D. L. GRUNES}

Highlight: Grass tetany, a magnesium (Mg) deficiency in grazing ruminants, often occurs simultaneously with periods of reduced solar radiation levels. The objective of this study was to determine if reduced radiation levels produce a chemical composition in grass indicative of a tetany-prone forage. Two grass species were exposed to three radiation levels $(8,25$, and $100 \%$ of actual) by shading with burlap cloth. The vegetatively growing forage was harvested at weekly intervals over a 5-week period during early spring.

Shaded forage had higher concentrations of $M g$ than did unshaded forage. However, shaded forage compared to forage grown in full sunlight would likely result in less $\mathrm{Mg}$ being available to the animal. The hypothesized inverse relationship between radiation and the incidence of grass tetany in Idaho, Nevada, and Utah is supported by field observations.

Grass tetany is a sometimes fatal nutritional disorder in cattle and sheep caused by a deficiency of available magnesium (Mg) (Grunes, 1973; Grunes et al., 1970; Metson et al., 1966; and Molloy, 1971). This $\mathrm{Mg}$ deficiency may be due to inadequate forage intake and thus reduced $\mathrm{Mg}$ intake, or to forage factors that reduce the availability of dietary Mg. Physiological stresses caused by a change in diet, parturition, lactation, increased age, transportation, etc. increase the animal's susceptibility to grass tetany.

Tetany occurs throughout the temperate regions of the world, predominantly while animals are on rapidly growing, immature grass pastures. The higher frequency of tetany on grass pastures compared to other forage types results in part because of lower $\mathrm{Mg}$ concentrations in grass than in other forages. For example, we have found that mean $\mathrm{Mg}$ concentrations in a number of grasses, legumes, and forbs native to the big sagebrushbunchgrass range were $0.14,0.26$, and

Authors are soil scientists, Agricultural Research Service, U.S. Department of Agriculture, Kimberly, Idaho, and U.S. Plant, Soil and Nutrition Laboratory, Ithaca, New York, respectively.

The research is a contribution from the Western Region, Agr. Res. Serv., U.S. Dep. Agr. Idaho Agricultural Experiment Station cooperating.

The authors appreciate the help of Arlene Florence and Harold Waggoner in the harvest ing, preparation, and analysis of plant samples; and to Dr. James $\mathrm{L}$. Wright for the radiation measurements.

Manuscript received July 17, 1973.

\section{$0.38 \% \mathrm{Mg}$, respectively.}

Not only do grasses normally contain lower $\mathrm{Mg}$ concentrations than do legumes and forbs but, also, a smaller amount of the $\mathrm{Mg}$ in the grass is available to the ruminant. This reduced availability is related to forage levels of $\mathrm{N}, \mathrm{K}, \mathrm{K} /(\mathrm{Ca}+$. $\mathrm{Mg}$ ), organic acids, higher fatty acids (HFA), and the protein:energy values all of which are higher for tetany-causing forage than for other forage (Grunes et al., 1970; Mayland and Gruncs, 1974; and Mayland et al. ${ }^{1}$ Consequently, any factor that increases the animal's $\mathrm{Mg}$ requirement, reduces $\mathrm{Mg}$ intake, or reduces dietary $\mathrm{Mg}$ availability will tend to produce a tetany situation.

Grass tetany occurs in southern Idaho and northern Nevada on monocultured grass rangelands during midspring. This occurrence coincides with the rainy season, when incident daily radiation may be reduced because of the increased cloud cover. For example, 7-day incident radiation values at Kimberly, Ida., ranged from about 50 to nearly $100 \%$ of potential clear-day values during April and May from 1966 to 1972. We therefore questioned whether the reduced radiation caused changes in forage chemical composition that were related to the incidence of tetany.

\footnotetext{
' Mayland, H. F., D. L. Grunes, and D. M. Stuart. 1974. Chemical composition of Agropyron desertorum as related to grass tetany. Accepted for publication, Agron. J. 66(3).
}

Previous research has shown that shaded grasses have lower dry matter and much higher crude protein (total N) than grasses grown in full sunlight (Burton et al., 1959; Deinum, 1966; Myhr and Saebo, 1969). The ash content of shaded forage is increased to levels sometimes twice that of unshaded plants because of higher concentrations of $\mathrm{K}, \mathrm{Mg}, \mathrm{Ca}$, and P. Cunningham and Nielsen (1965) reported greater cation concentrations in plants grown during cloudy weather than in plants grown during sunny weather.

Low radiation levels limit the energy available for synthesizing carbon compounds in the plant. Consequently, $\mathrm{NO}_{3}-\mathrm{N}$ accumulates, and concentrations of total water-soluble carbohydrate (TWSC) or other carbohydrate fractions in shaded grass may be only half the concentration found in unshaded grass (Deinum, 1966; Hight et al., 1968; Myhr and Saebo, 1969; and Paulsen and Smith, 1969).

Shading (22 to $30 \%$ of full sunlight) significantly reduced dry matter intake as well as digestiblity of forage by sheep (Deinum et al., 1968; and Hight et al., 1968). The reduced intake of shaded forage was attributed to its lower soluble sugar content.

There is considerable evidence that reduced radiation changes the chemical composition of forage. Some of these changes may be associated with the tetany syndrome because of their effects on reducing $\mathrm{Mg}$ intake and availability to ruminants. The objective of this study was to determine the effects of reduced radiation levels upon the chemical composition of two semiarid grass species, and to evaluate such changes in relation to the $\mathrm{Mg}$ nutrition in animals.

\section{Field Methods}

Established plots of 'Nordan' crested wheatgrass (Agropyron desertorum (Fisch.) Schult.) and basin wildrye (Elymus cinereus Scribn. and Merr.) near 
Kimberly, Ida., were selected for this study. The soil is a course, silty, Durixerollic calcorthid known as Portneuf silt loam. The soil characteristics follow:

Organic carbon $(\%)$

1.1

$\mathrm{pH}$ saturated paste

7.7

Saturation water content (\%)

40.0

Conductivity of saturation extract

(mmhos)

Cation exchange capacity

(meq/100 g)

0.5

$\mathrm{CaCO}_{3}$ equivalent (\%)

20.0

3.0

$\mathrm{NH}_{4} \mathrm{OAc}$ extractable cations (meq/100 g) $\mathrm{Na}$

0.1

$\mathrm{K}$

1.0

5.0

$\mathrm{Ca}$

15.0

Water extractable cations - saturation extract (meq/liter)

$\begin{array}{ll}\mathrm{Na} & 0.5 \\ \mathrm{~K} & 0.5 \\ \mathrm{Mg} & 1.8 \\ \mathrm{Ca} & 3.8\end{array}$

The shading was imposed by a single thickness of burlap cloth $2.5 \times 6 \mathrm{~m}$ supported at a height of $1.5 \mathrm{~m}$ in an east-to-west orientation. The shading was installed April 1, 1968, and remained until May 10, 1968. Midday radiation levels measured with an Eppley $180^{\circ}$ pyranometer at the $0.3-\mathrm{m}$ height indicated that the shaded plots had 25\% $\left(R_{25}\right)$ of clear-day radiation levels $\left(R_{100}\right)$. That is to say that the $R_{25}$ plots had a light transmission of $25 \%$ of full sunlight. The average radiation values (unshaded) were 547 and 638 langleys per day for April and May 1968, respectively (Fig. 1). These values were 106 and $100 \%$ of average values (1966-1972), and 82 and $81 \%$ of the potential clear-day values, respectively. (Potential clear-day values are calculated radiation values which do not consider effects of atmospheric absorption and reflection of light.) The possible changes in spectral characteristics resulting from the burlap shade screens were not evaluated.

A second shading level was induced by a double thickness of burlap cloth. The light intensity transmitted by this treatment, $R_{08}$, was $8 \%$ of full sunlight. Data for the $R_{08}$ treatment were similar to those obtained for the $R_{25}$ and were therefore omitted to save space. Responses of the various chemical parameters to reduced radiation were generally greater for the $R_{08}$ than for the $R_{25}$ treatment.

The two shading treatments were joined end to end on each of the two forage plots. Forage samples were randomly harvested from the area within the plot after allowing for a $2-\mathrm{m}$ border on the east and west ends, a $0.2-\mathrm{m}$ border on the north, and a $1.3-\mathrm{m}$ border on the south side. Forage grown under full sunlight, $R_{100}$, was harvested from the area adjacent to all sides of the shaded plots,
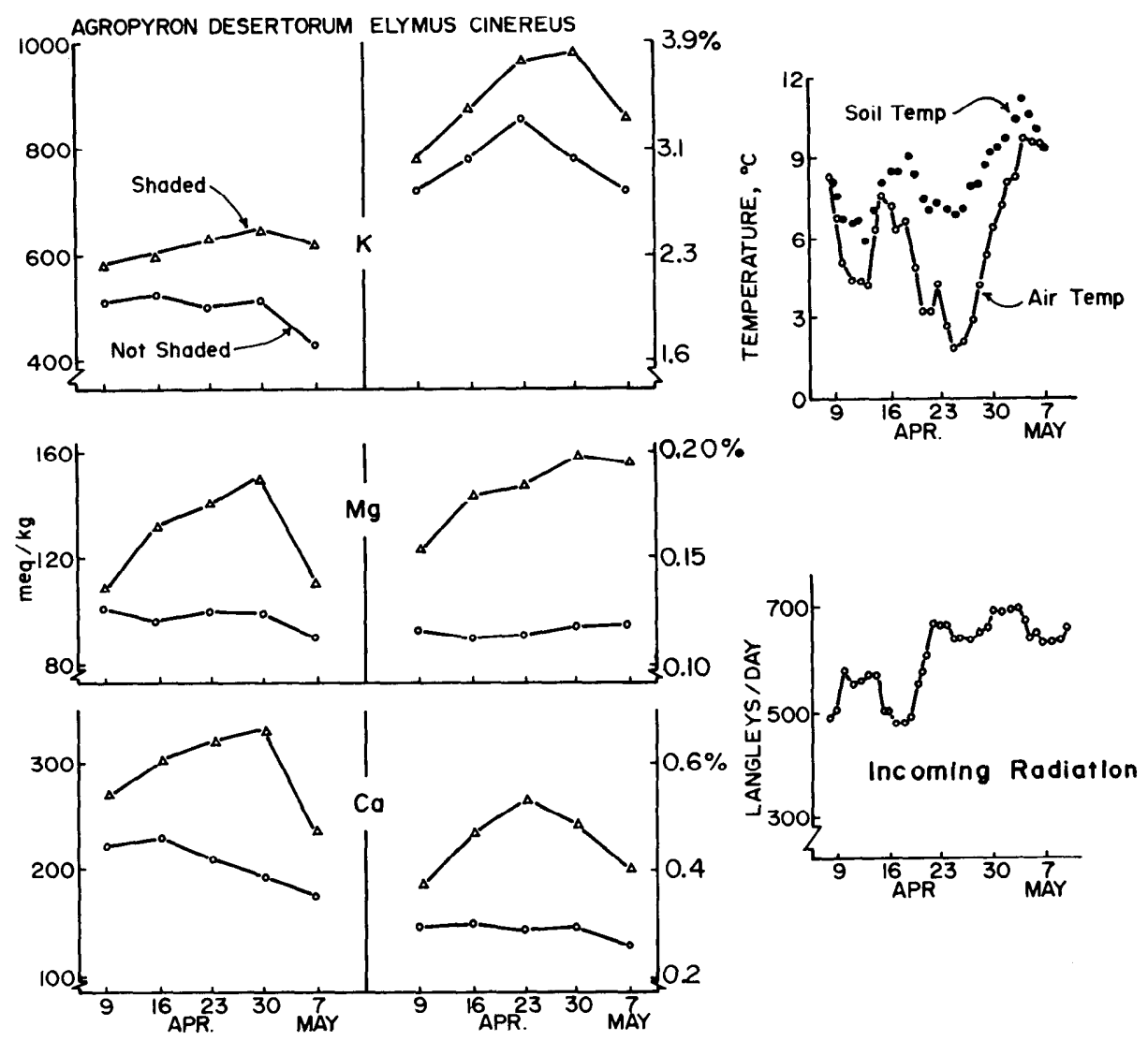

Fig. 1. Concentration of $\mathrm{K}, \mathrm{Mg}$, and $\mathrm{Ca}$ in two grass species as affected by shading; and the 5-day moving means for incoming radiation, air temperature at the 1.4-m height, and bare soil temperature at the $10-\mathrm{cm}$ depth. (To change meq $/ \mathrm{kg}$ to percent, multiply $\mathrm{K}$ by $0.00391, \mathrm{Mg}$ by 0.00122 , and Ca by 0.00200.)

but about $2 \mathrm{~m}$ away to avoid any shading effect.

Forage samples were harvested at the 3- to $5-\mathrm{cm}$ height during midmorning to avoid diurnal changes in parameters such as carbohydrates. Plant samples were harvested at weekly intervals from different areas of the same plots. Data represent forage harvested during the vegetative growth (preboot) stage. Forage samples were freeze-dried immediately after harvest. Water content of the freeze-dried material was generally less than one percent as determined by weight loss over $\mathrm{P}_{2} \mathrm{O}_{5}$ dessicant. Dry matter content of fresh samples was determined by weighing before and after freeze-drying. Dried samples were ground to pass 40-mesh sieve and stored in glass bottles at ambient temperatures.

Five-day moving means were calculated for accumulative daily radiation and for average daily $[(\min +\max ) / 2]$ soil (10-cm depth - bare cover) and air temperatures obtained from the Kimberly Climatological Station adjacent to the plots. Air and soil temperatures, measured only at sampling time, were lower for the shaded than for the unshaded treatments, but these differences seldom exceeded $2^{\circ} \mathrm{C}$.

\section{Laboratory Methods}

Plant samples were dry-ashed overnight in pyrex beakers at $500^{\circ} \mathrm{C}$, and subsequently treated to assure the loss of carbonates and nitrates and to dehydrate the silica, which was removed by filtration through Whatman No. 42 (T. Greweling, The Chemical Analysis of Plant Tissue, Cornell University Agron. Mimeo. 6622). The filtrate was analyzed for $\mathrm{Na}, \mathrm{K}, \mathrm{Mg}$, and $\mathrm{Ca}$ by atomic absorption. Aliquots reserved for $\mathrm{Mg}$ and $\mathrm{Ca}$ analysis contained $1500 \mathrm{ppm}$ Sr to minimize $\mathrm{Al}$ and $\mathrm{P}$ interference with $\mathrm{Ca}$.

Total $\mathbf{P}$ was determined by the colorimetric molybdenum-blue method (Chapman and Pratt, 1961), modified by substituting 1-amino-2-napthol-4-sulfonic acid for $\mathrm{SnCl}_{2}$ as reducing agent. Chloride was determined by potentiometric titration with $\mathrm{AgNO}_{3}$. Nitrate-N was determined by the phenoldisulfonic acid method. Sulfate-S was extracted from $0.5 \mathrm{~g}$ plant samples by shaking for 25 minutes with $50 \mathrm{ml} 0.35 N$ acetic acid plus $0.5 \mathrm{~g}$ carbon black (Elf 1, channel black), filtered, and then $\mathrm{SO}_{4}-\mathrm{S}$ determined by the $\mathrm{BaSO}_{4}$ turbidimetric technique (Stewart and Porter, 1969).

Ash and ash alkalinity (Van Tuil et al., 
1964) values were obtained after ignition at $550^{\circ} \mathrm{C}$ for 2 hours after reaching temperature. Higher fatty acids (HFA) were determined by titration following saponification and separation into a petroleum ether phase (Immink et al., 1965). Cations minus anions (C - A) were calculated on a milliequivalent basis as $\left(\mathrm{Na}^{+}+\right.$ $\left.\mathrm{K}^{+}+\mathrm{Mg}^{++}+\mathrm{Ca}^{++}\right)$minus $\left(\mathrm{Cl}^{-}+\right.$total $\mathrm{P}$ as $\left.\mathrm{H}_{2} \mathrm{PO}_{4}^{-}+\mathrm{NO}_{3}^{-}+\mathrm{SO}_{4}^{-}\right)$. The ratio $\mathrm{K} /(\mathrm{Ca}+\mathrm{Mg})$ was calculated on a milliequivalent $/ \mathrm{kg}$ basis.

Total aconitic acid was determined by polarography (Patterson et al., 1972). Total water-soluble carbohydrates (TWSC) were determined as reducing sugars (Metson et al., 1966). Total N (including $\mathrm{NO}_{3}$ ) was determined by the Kjeldahl method.

Forage dry matter concentration was calculated as dry weight divided by fresh weight $X 100$. Chemical data are given on a dry matter basis. The paired $t$-test (Snedecor and Cox, 1967) was used to test various treatments for significant differences.

\section{Results and Discussion}

Shaded grass forage contained significantly higher concentrations of $\mathrm{K}, \mathrm{Mg}$, and $\mathrm{Ca}$ (Table 1) than did unshaded forage. Relative increases in $\mathrm{Mg}$ and $\mathrm{Ca}$ on a $\mathrm{meq} / \mathrm{kg}$ basis (Fig. 1) were greater than those of $\mathrm{K}$, resulting in lower $\mathrm{K} /(\mathrm{Ca}+$ $\mathrm{Mg}$ ) values in the shaded compared to the unshaded forage (Table 1). The increased $\mathrm{Mg}$ concentration and the reduced $\mathrm{K} /(\mathrm{Ca}$ $+\mathrm{Mg}$ ) values resulting from reduced radiation levels could be beneficial in reducing the incidence of tetany. However, the mean $\mathrm{K} /(\mathrm{Ca}+\mathrm{Mg})$ value of 2.4 for basin wildrye is still greater than the commonly accepted threshold value of 2.2 , above which the incidence of tetany rapidly increases (Grunes et al., 1970).

For the unshaded plants, concentrations of $\mathrm{K}$ and $\mathrm{Ca}$ in both plant species decreased with increased physiological age (Fig. 1). Concentrations of $\mathrm{Mg}$ decreased only in the older crested wheatgrass forage. For the shaded plants, with the exception of $\mathrm{Mg}$ concentrations for basin wildrye, mineral concentrations increased until the third or fourth harvest, then declined noticeably. The decline is attributed to a dilution effect brought about by increased concentrations of synthesized carbon material in the forage.

The forage $\mathrm{Cl}$ and $\mathrm{SO}_{4}-\mathrm{S}$ concentrations were greatly increased by shading (Table 1). Shading resulted in a 5 -fold increase in $\mathrm{NO}_{3}-\mathrm{N}$ concentration compared to unshaded, but the increase was significant only for basin wildrye. The $P$ level was reduced by the shading treatment, but this reduction was significant only for basin wildrye.

Total forage $\mathrm{N}$ was increased and TWSC decreased by shading (Table 1) so that the N/TWSC ratios averaged $75 \%$ greater in both species when shaded. This protein:energy imbalance in grazed forage might conceivably reduce the availability of forage $\mathrm{Mg}$ to the ruminant (Grunes et al., 1970; and Mayland et al. ${ }^{1}$ ).

Total cations $\left(\mathrm{C}=\mathrm{Na}^{+}+\mathrm{K}^{+}+\mathrm{Mg}^{++}+\right.$ $\mathrm{Ca}^{++}$) were increased about $28 \%$ in the shaded forage, and anions $\left(\mathrm{A}=\mathrm{Cl}^{-}+\right.$ total $\mathrm{P}$ as $\mathrm{H}_{2} \mathrm{PO}_{4}^{-}+\mathrm{NO}_{3}^{-}+\mathrm{SO}_{4}^{-}$) were increased about $45 \%$ when compared to unshaded forage (Table 1). However, because of the relative magnitudes of $\mathrm{C}$ and $\mathrm{A}$, the cation minus anion $(\mathrm{C}-\mathrm{A})$ values were increased $21 \%$ for crested wheatgrass and $9 \%$ for basin wildrye by the shading treatment. These values are compared to 29 and $13 \%$ increases in ash alkalinity of the two species, respectively. Ash alkalinity is theoretically equivalent to $\mathrm{C}-\mathrm{A}$, but we have generally found ash alkalinity values to be greater than those of C - A (Mayland et al. ${ }^{1}$ ). The increases in C - A theoretically are accompanied by stoichiometric increases in organic acids so as to maintain electrical neutrality in the plant. From the changes in $\mathrm{C}$ $A$ and ash alkalinity, we conclude that total organic acid concentrations were increased by the reduction in radiation levels. The possible detrimental effect of high organic acid levels on reducing $\mathrm{Mg}$ availability to ruminants has been pointed out by Prior et al., 1973.

Total aconitic acid was also increased

Table 1. Effects of shading on mean chemical composition of Agropyron desertorum and Elymus cincreus during spring growth, 1968 . Data are means of 5 weekly harvests. ${ }^{1}$

\begin{tabular}{|c|c|c|c|c|}
\hline \multirow[b]{2}{*}{ Component } & \multicolumn{2}{|c|}{ Agropyron desertorum } & \multicolumn{2}{|c|}{ Elymus cinereus } \\
\hline & $R_{100}$ & $\mathrm{R}_{2 s}$ & $R_{100}$ & $\mathrm{R}_{2 s}$ \\
\hline $\mathrm{Na}(\%)$ & 0.05 & 0.06 & 0.05 & 0.06 \\
\hline $\mathbf{K}(\%)$ & 1.9 & $2.3^{*}$ & 3.0 & $3.5^{*}$ \\
\hline $\operatorname{Mg}(\%)$ & 0.12 & $0.15^{*}$ & 0.11 & $0.18 * *$ \\
\hline $\mathrm{Ca}(\%)$ & 0.42 & $0.62 *$ & 0.29 & $0.46 * *$ \\
\hline $\mathrm{P}(\%)$ & 0.22 & 0.20 & 0.27 & $0.21 *$ \\
\hline $\mathrm{Cl}(\%)$ & 0.57 & $0.81^{*}$ & 1.06 & $1.40 * *$ \\
\hline $\mathrm{NO}_{3}-\mathrm{N}(\mathrm{ppm})$ & 200 & 630 & 370 & $1870^{*}$ \\
\hline $\mathrm{SO}_{4}-\mathrm{S}(\mathrm{ppm})$ & 450 & $850^{*}$ & 560 & $940^{*}$ \\
\hline $\mathrm{K} /(\mathrm{Ca}+\mathrm{Mg})$ (meq basis) & 1.6 & $1.4 * *$ & 3.3 & $2.4 * *$ \\
\hline TWSC $(\%)$ & 20.0 & 15.0 & 15.0 & 11.0 \\
\hline Total N $(\%)$ & 4.0 & $5.1 * *$ & 3.9 & $5.1 * *$ \\
\hline N:TWSC & 0.21 & $0.36^{*}$ & 0.29 & $0.53 *$ \\
\hline Sum cations $(\mathrm{C})(\mathrm{meq} / \mathrm{kg})$ & 820 & $1050 * *$ & 1020 & $1290^{* *}$ \\
\hline Sum anions $(\mathrm{A})(\mathrm{meq} / \mathrm{kg})$ & 270 & $390^{*}$ & 450 & $650 *$ \\
\hline $\mathrm{C}-\mathrm{A}(\mathrm{meq} / \mathrm{kg})$ & 550 & $660^{*}$ & 570 & $640^{*}$ \\
\hline Ash alkalinity (meq/kg) & 550 & $720^{* *}$ & 590 & $660^{*}$ \\
\hline Aconitic acid (meq/kg) & 270 & 320 & 420 & $490 * *$ \\
\hline Higher fatty acids (meq $/ \mathrm{kg}$ ) & 96 & $130^{*}$ & 95 & $110^{*}$ \\
\hline Dry matter $(\%)$ & 34.5 & 33.1 & 29.5 & $23.7 * *$ \\
\hline Height $(\mathrm{cm})$ & 28 & $15^{* *}$ & 21 & $18^{*}$ \\
\hline
\end{tabular}

by the shading treatment (Table 1). This acid accounted for one-half of the total organic acid concentration (as inferred from $\mathrm{C}-\mathrm{A}$ or ash alkalinity) in crested wheatgrass and for three-fourths of the total concentration in basin wildrye. These proportions were similar in both the shaded and unshaded forage.

Organic acids, especially aconitic acid, may be important in chelating $\mathrm{Mg}$ and reducing its availability to the animals, especially in marginal $\mathrm{Mg}$ situations (Grunes, 1973; and Grunes et al., 1970). Therefore an increase in organic acid content could be important in causing a $\mathrm{Mg}$ deficiency in ruminants and grass tetany, especially if available $\mathrm{Mg}$ is borderline.

Higher fatty acids, e.g., palmitic and linolenic acids, were significantly increased by shading. The higher fatty acids are capable of forming water-insoluble soaps with $\mathrm{Mg}$ and $\mathrm{Ca}$, thus reducing the availability of $\mathrm{Mg}$ and $\mathrm{Ca}$ to the animal (Immink et al., 1965).

Shaded forage tended to have a lower dry matter content than did unshaded forage (Table 1), and this may relate to $\mathrm{Mg}$ nutrition in two ways. First, as dry matter content decreases, a greater intake of feed is necessary to meet the dry matter (including $\mathrm{Mg}$ ) requirements of the animal. Second, as the forage dry matter content decreases, the feed becomes "slushy" and the consumed forage is retained in the digestive system for shorter periods. This shorter retention time of the ingesta results in less oppor- 
tunity for Mg absorption (Molloy, 1971).

Changes in the $\mathrm{Mg}$ and $\mathrm{K} /(\mathrm{Ca}+\mathrm{Mg})$ values of forage grown under reduced radiation levels, compared to full sunlight, should favor a reduction in tetany cases. However, changes in other factors such as $\mathrm{K}, \mathrm{N}$, TWSC, organic acids, higher fatty acids, and dry matter content would likely result in reduced intake of dry matter and $\mathrm{Mg}$ or in reduced availability of $\mathrm{Mg}$ to the ruminant.

Reduced solar radiation may be a factor in the etiology of grass tetany. The incidence of grass tetany in Idaho, Nevada, and Utah appears to be greater if radiation levels are low in April. For example, daily radiation values during April averaged 437, 547, and 551 langleys per day during 1967, 1968, and 1969, respectively. The incidence of grass tetany for those respective years was severe, light, and near zero in the three-state area.

The reduced radiation in the threestate area coincides with the spring rainy period. Thus, more clouds result in less total radiation, but also in a greater opportunity for rain. In fact, for the 1967 to 1971 period, the correlation of April precipitation with average monthly radiation was $r=-0.97$. Therefore, while there is a good relationship between shading or reduced radiation and the incidence of tetany, it might also be argued that the causative factor is improved plant growth resulting from improved moisture conditions and not the reduced radiation per se. Final proof must await carefully conducted growth chamber experiments where radiation levels are varied for given levels of soil moisture and temperature. For the present, it appears that reducing the radiation on either of the semiarid grass species used in this study results in a change in chemical composition. The net effect of reduced radiation levels would probably be a reduction in $\mathrm{Mg}$ availability to the grazing animal.

\section{Literature Cited}

Burton, G. W., J. E. Jackson, and F. E. Knox. 1959. The influence of light rcduction on the production, persistence, and chemical composition of coastal Bermuda grass (Cynodon dactylon). Agron. J. 51:537-542.

Chapman, H. D., and P. F. Pratt. 1961. Methods of analysis for soils, plants, and waters. Div. Agr. Sci., Univ. of California, Riverside.

Cunningham, R. K., and K. F. Nielsen. 1965. Cation-anion relationships in crop nutrition. 5. The effects of soil temperature, light intensity and soil-water tension. J. Agr. Sci., Cambridge, 64:379-386.

Deinum, B. 1966. Climate, nitrogen and grass. Research into the influence of light intensity, water supply and nitrogen on the production and chemical composition of grass. Meded. Landb. Hogesch., Wageningen, 66(11). $91 \mathrm{p}$.

Deinum, B., A. J. H. Van Es, and P. J. Van Soest. 1968. Climate, nitrogen and grass. 2. The influence of light intensity, temperature, and nitrogen on vivo digestibility of grass and the prediction of these effects on some chemical procedures. Netherlands J. Agr. Sci. 16:217-223.

Grunes, D. L. 1973. Grass tetany in cattle and sheep. p. 113-140. In: A. G. Matches (ed.) Antiquality components of forages. Crop Sci. Soc. of Amer. Spec. Public. 4. Madison, Wisc.

Grunes, D. L., P. R. Stout, and J. R. Brownell. 1970. Grass tetany in ruminants. Advance. Agron. 22:331-374.

Hight, G. K., D. P. Sinclair, and R. J. Lancaster. 1968. Some effects of shading and nitrogen fertilizer on the chemical composition of freeze-dried and oven-dried herbage fed to sheep. New Zealand J. Agr. Res. 11:286-302.

Immink, H. J., J. H. Geurink, and W. B. Deijs. 1965. The determination of the higher fatty acids in grass and cow feces. Jaarboek, Int. Biol. Scheik., p. 103-107.

Mayland, H. F., and D. L. Grunes. 1974. Magnesium concentration in Agropyron desertorum fertilized with $\mathrm{Mg}$ and $\mathrm{N}$. Agron. J. 66:79-82.

Metson, A. J., W. M. H. Saunders, T. W. Collie, and V. W. Graham. 1966. Chemical composition of pastures in relation to grass tetany in beef breeding cows. New Zealand J. Agr. Res. 9:410-436.

Molloy, L. F. 1971. Hypomagnesaemic tetany and the chemistry of dietary calcium and magnesium. New Zealand Soil Bur. Sci. Rep. 5. $21 \mathrm{p}$.

Myhr, K., and S. Saebo. 1969. The effects of shade on growth, development, and chemical composition in some grass species. Forsk. Fors. Landbr. 20:297-315 (Herb. Abstr. 40:2827).

Patterson, R. P., D. L. Grunes, and D. J. Lathwell. 1972. Influence of root-zone temperature and $P$ supply on total and inorganic $\mathbf{P}$, free sugars, aconitate, and soluble amino $\mathrm{N}$ in corn. Crop Sci. 12:227-230.

Paulsen, G. P. M., and Dale Smith. 1969. Organic reserves, axillary bud activity, and herbage yields of smooth brome grass as influenced by time of cutting, nitrogen fertilization, and shading. Crop Sci. 9:529-534.

Prior, R. L., D. L. Grunes, R. P. Patterson, F. W. Smith, H. F. Mayland, and W. J. Visek. 1973. Partition column chromatography for quantitating effects of fertilization on plant acids. J. Agr. Food Chem. 21:73-77.

Snedecor, G. W., and W. G. Cox. 1967. Statistical methods, 6 th ed. Iowa State Univ. Press, Ames.

Stewart, B. A., and L. K. Porter. 1969. Nitrogen-sulfur relationships in wheat (Triticum aestivum L.), corn (Zea mays), and beans (Phaseolus vulgaris). Agron. J. 61:267-271.

Van Tuil, H. D. W., J. E. M. Lampe, and W. Dijkshoorn. 1964. The possibility of relating the ash alkalinity to the organic-salt content. p. 157-160. In: 1964 Yearbook, Institute for Biological and Chemical Research on Field Crops and Herbage, Wageningen, The Netherlands. 